\title{
Anogenital warts: an update on human papilloma virus, clinical manifestations and treatment strategies
}

\section{Anogenital siğiller: İnsan papilloma virüsü, klinik bulguları ve tedavi stratejileri üzerine bir güncelleme}

\author{
Arzu Kilic ${ }^{1}$, Ulku Mete Ural ${ }^{2}$
}

${ }^{1}$ Dept. of Dermatology, Balikesir University, Faculty of Medicine, Balikesir, Turkey, ${ }^{2}$ Dept. of Gynecology and Obstretrics, Bolu Abant Izzet Baysal University, Faculty of Medicine, Bolu, Turkey

\begin{abstract}
Anogenital warts is a major health problem caused by human papilloma virus (HPV). To date, more than 200 subtypes of HPV exist. Depending on the type of HPV and the immune status of the patient, various clinical forms may appear. The most detected types are HPV-6 and 11 which are responsible for approximately 90\% of anogenital warts. High oncogenic strains HPV types 16 and 18 are responsible not only for cervical cancer, but also other cancers such as vagina, vulva, penile, anus, head and neck. Besides, anogenital warts impact the individual's quality of life leading significant psychosocial problems. Treatment options for anogenital warts include cytodestructive, immune-mediated and surgical therapies. Treatment choice depends on the location, number, and size of the warts; patient situation (eg. pregnancy, ability to comply with therapy, immunosuppression); availability of clinical expertise; and patient preferences, cost, and convenience. This article updates the epidemiological, etiological, clinical features and therapeutic choices in anogenital warts.
\end{abstract}

Key words: anogenital warts, human papilloma virus, treatment

\section{O̊zet}

Anogenital siğiller insan papilloma virüsünün (HPV) neden olduğu önemli bir sağlık sorunudur. Bugüne kadar, 200'den fazla HPV alt tipi saptanmıştır. HPV tipine ve hastanın bağışıklık durumuna bağlı olarak, anogenital siğillerde çeşitli klinik formlar gözlenebilir. En çok tespit edilen tipler HPV-6 ve HPV 11 olup anogenital siğillerin yaklaşı\% 90'ından sorumludur. Yüksek onkojenik suşlar HPV tip 16 ve 18 sadece servikal kanserden değil, vajina, vulva, penis, anüs, baş ve boyun gibi diğer kanserlerden de sorumludur. Ayrıca, anogenital siğiller, bireyin yaşam kalitesini etkileyerek önemli psikososyal sorunlara neden olur. Anogenital siğiller için tedavi seçenekleri arasında destrüktif, immün modülatör ve cerrahi tedaviler bulunmaktadır. Tedavi seçimi siğillerin yeri, sayısı ve büyüklügüne; hastanın durumuna (örneğin, hamilelik, tedaviye uyma yeteneği, immün baskılama); klinisyenin tecrübesine; ve hastanın tercihleri ve rahatlı̆̆ına bağlıdır. Bu makale anogenital siğillerdeki epidemiyolojik, etiyolojik, klinik özellikleri ve tedavi seçeneklerini güncellemektedir.

Anahtar kelimeler: anogenital siğiller, insan papilloma virüsü, tedavi

Corresponding author: Arzu Kilic, Dept. of Dermatology, Balikesir University, Faculty of Medicine, Balikesir, Turkey, Phone: +90 2666121010 - 4430, E-mail: Kilicarzu1976@gmail.com

Received: 19 June 2019 Accepted: 28 June 2019

Conflicts of Interest: None

Funding: None 


\section{Introduction}

Anogenital warts (AGW) are one of the common sexually transmitted infections (STI)s in the world and are caused by human papillomavirus (HPV). AGWs also called as genital warts, anogenital condylomas or condylomata acuminata-are lesions that develop on the skin and mucosa due to infection with some types of HPV. ${ }^{1-4}$ In this article, the epidemiology, etiology, clinical features of anogenital warts and treatment choices are reviewed in the light of current literature.

\section{Epidemiology}

Approximately $60 \%$ of sexually active people have been infected with genital HPV at any time during their life. There are more than 500,000 new cases of AGWs annually. Peak prevalence of HPV infection typically occurs after sexual activity, between the ages of 15 to 25 years. Today it is known that sexual intercourse is not necessary for the development of HPV infection. Skin-to-skin or mucosa-to-mucosa contact is enough for the transmission of the virus. ${ }^{1-7}$

Human papilloma virus is the cause of not only benign diseases (anogenital condylomas) but also pre-malignant lesions and different cancers. ${ }^{2-3}$ High-risk HPV subtypes (HPV 16 and HPV 18) are the causes of approximately $70 \%$ of invasive cervical cancer and it is estimated that 500,000 cases of cervical cancer occur each year worldwide. ${ }^{6-9}$ Risk factors for the development of AGWs and oral warts include young age, early onset of sexual activity, multiple sexual partners, a history of sexual transmitted disease, tobacco use, failure to use condom, being uncircumcised. 2,4 Epidemiologic data and prevalence in childhood genital warts are still limited. ${ }^{10}$

\section{Etiopathogenesis}

Human papilloma virus is a double-stranded, non-enveloped DNA virus. To date more than 200 different genotypes have been identified. Over 40 mucosal HPV genotypes can infect the genital tract. HPVs are categorized as high or low risk according to their oncogenic potential. HPV types 6 and 11 are responsible for ap- proximately 90\% of genital warts while HPV types 16 and 18 are responsible for cervical cancers. HPV has a high tropism for squamous epithelium. Basal keratinocytes are thought to be the primary target for infection, by this way they can induce cellular proliferation.-4, 11-15 After infection, HPV typically requires an incubation period ranging from a few weeks to 8 months before the appearance of clinical manifestations. Lesions appear approximately 2 to 3 months after initial contact. HPV has the ability of lying dormant within epithelial cells for a prolonged time. Infection may be subclinical during the individual's life with no clinically apparent warts. Only about 10 to $15 \%$ of infections persist, and approximately 10 to $15 \%$ of these persistent infections result in cancer. ${ }^{11-15}$

\section{Clinical Manifestations}

Warts are typically small, discrete, smooth papules/ plaques that can occur both separately or in groups. They are especially localized in anogenital areas, such as the vulva, penis, groin, perineum, perianal skin and/or mucosal surfaces. Due to the varieties in sexual behaviours, they may also occur on the lips and/or mucosa including anus, pharynx and larynx. The lesions may demonstrate various morphological features such as filiform, exophytic, papillomatous, verrucous, hyperkeratotic, cerebriform, fungating, or cauliflower-like and the color is also variable ranging from skin-colour to erythematous, and/or brown-hyperpigmented. After their initial appearance, AGWs may increase in number and size or silently regress over time. ${ }^{1-4,6,8}$

Buschke-Lowenstein tumors are slow-growing giant condylomata accuminata of the anogenital region. They are locally destructive, low grade in situ epithelial cancer with a low rate of metastasis. ${ }^{4,16}$

Bowenoid papulosis and erythroplasia of Queyrat are two conditions both of which are carcinoma-in-situ histopathologically and they are characterized clinically by small flat pigmented papules and erythematous plaques on the external genitalia, respectively. When encountered with pigmented, erosive, bleeding cases, biopsy 
from the lesions should be taken in order to rule out carcinoma. ${ }^{4,6,8}$

\section{Special conditions}

Anogenital warts in children is another major issue to be discussed in depth. The physicians should suspect for sexual abuse when they encountered with anogenital warts in children. ${ }^{10,17}$

Anogenital warts in pregnancy: Due to the reduced cellular immunity and increased vascularity in genital tractus in pregnancy, AGWs tend to grow more rapidly, to be more in number and friable. Besides, HPV can be transmitted vertically from the mother to the child during delivery which may result in neonatal and congenital, oral, or conjunctival lesions. ${ }^{18,19}$

Anogenital warts in immunsupression: Immuncompromised individuals have a higher risk of malignant transformation and higher risk of coinfection with more than one HPV type and also have a higher viral load. AGWs are larger and more treatment resistant with higher recurrence rates. $^{20}$

\section{Comorbidities}

Physcosocial problems and sexual dysfunction: Warts can bring about significant anxiety or distress for the patient and her/his sexual partner because of the disfiguring appearance of the warts. Patients usually have concerns about risk of cancer, and transmission of other STDs. The disease has negative psychological and social effects both for males and for females, and it affects life quality adversely. The patients usually have feelings of embrassment and guilty. ${ }^{21,22}$

Presence of other sexually transmitted diseases: It is estimated that $20-34 \%$ of affected patients have concomitant STDs. ${ }^{23}$

\section{Neoplasia:}

Cervical cancer: High-risk HPV subtypes (HPV 16 and HPV 18) are the causes of approximately $70 \%$ of invasive cervical cancer and it is estimated that 500,000 cases of cervical cancer occur each year worldwide. ${ }^{9-24}$

A study of paraffin-embedded samples of 10,575 cases of cervical cancer demonstrated that the most common HPV types were 16, 18, 31, 33, 35, 45, 52, and 58; HPV types 16 and 18 represented $71 \%$ of the cases overall. ${ }^{25}$

Other anogenital cancers: Vaginal, vulvar, penile and anal cancers and their precancerous precursors such as vulvar intraepithelial neoplasia (IN), penile IN, anal IN are other associated neoplasies. Individuals with AGWs are at increased risk for head, and neck cancers. ${ }^{26-30}$

Obstruction: External AGWs invading anal canal and/ or urethra may cause defecation problems, bleeding and mixion problems as a result of obstruction. ${ }^{31}$

\section{Differential Diagnosis}

Other cutaneous conditions including normal skin variations, other infectious and inflammatory diseases may mimic AGWs. Differential diagnoses include pearly penile papules, Fordyce spots, acrochordons, condylomata lata of syphilis, molluscum contagiosum, granuloma annulare, lichen nitidus, lichen planus, seborrheic keratosis, epidermal nevus, lymphangioma circumscriptum, lymphogranuloma venereum, scabies, syringomas, traumatic neuromas, schwannomas, and squamous cell carcinoma. ${ }^{4,8}$

\section{Treatment}

The basic indication for treatment of AGWs is reducing of symptoms (pruritus, bleeding, burning, tenderness, vaginal discharge, pain, obstruction of the vagina, dyspareunia) or psychologic anxiety. ${ }^{32,33}$ There is no medical indication for treatment of asymptomatic warts incidentally noted on physical examination, but patients should be made aware of the presence of these lesions. Warts do not pose serious risks to health or fertility. In placebo controlled treatment trials, spontaneous regression occurred in up to $40 \%$ of cases. Patients should be informed that prolonged treatment with frequent follow-up is often necessary. They should also understand that medical and surgical therapies lead to clearance of warts in 35 to 100 percent of patients in 3 to 16 weeks, ${ }^{34}$ but do not necessarily eradicate all HPV infected cells. ${ }^{33,35,36}$ The likelihood of recurrence is variable depending on the patient's medical condition, im- 
mune status, and the extent of disease, but 20 to $30 \%$ of patients have a recurrence within a few months. ${ }^{37} \mathrm{Nev}-$ ertheless, most HPV infections associated with genital warts in immune competent patients are cleared within two years. ${ }^{38}$

Both medical and surgical options are available for treatment (Table 1). There is no high quality evidence that any treatment is significantly better than others or suitable for whole patients and all types of warts; therefore, treatment choice depends on the location, number, and size of the warts; patient situations (eg, pregnancy, ability to comply with therapy, immunocompromised); availability of resources and clinical expertise; and patient preferences after considering side effects, cost, and convenience. ${ }^{39,40}$

Medical therapies are generally tried first; if the patient has not responded to the initial medical treatment after 3 weeks or total clearance has not happened by 6 to 12 weeks, a different medical therapy can be administered. ${ }^{41}$ Surgical therapy is typically reserved for patients with extensive and/or bulky lesions and those who have failed to respond adequately to medical therapy. Surgery results in high initial clearance rates (90 to 100\%), but recurrence rates are similar to those with medical therapy. $^{34}$

\section{Medical therapy}

All medical therapies are most useful for patients with limited disease (eg, $\leq 5$ small warts). ${ }^{41}$ Podophyllotoxin (podofilox), imiquimod, sinecatechins, and topical interferon can be self-administered. Vaginal warts can only be treated with trichloroacetic acid (TCA), bichloroacetic acid (BCA), and interferons. TCA has no systemic absorption and no fetal side effects reported; therefore, it is the preferred treatment for pregnant women. In general, if the patient has not responded to the initial treatment after approximately 3 weeks or total clearance has not occurred by 6 to 12 weeks, it is appropriate to use another treatment. ${ }^{42}$

\section{Cytodestructive therapies}

Podophyllotoxin (podofilox): Podophyllotoxin (podofilox) consists of the biologically active component of podophyllum resin. The patient applies a $0.5 \%$ gel or solution to external genital warts by a cotton swab twice daily for three sequential days, then stops treatment for four days, and repeats this phase weekly up to four times. ${ }^{33,43}$ No more than $0.5 \mathrm{~mL}$ of podofilox should be applied in one day. Broad areas $\left(10 \mathrm{~cm}^{2}\right.$ or more) should not be treated at one time because pain is likely when the area becomes necrotic. Podophyllotoxin is avoided in pregnancy.

Table 1. Treatment modalities of anogenital warts

\begin{tabular}{|c|c|}
\hline Medical therapy & Surgical therapy \\
\hline Cytodestructive therapies & Ablative therapies \\
\hline Podophyllotoxin (podofilox) & Cryoablation (Liquid nitrogen, Nitrous oxide) \\
\hline Podophyllum resin & Laser ablation \\
\hline Trichloroacetic acid & Electrocautery \\
\hline Bichloroacetic acid & Ultrasonic aspiration \\
\hline \multicolumn{2}{|l|}{ Fluorouracil } \\
\hline Immune-mediated therapies & Excisional therapies \\
\hline \multicolumn{2}{|l|}{ Imiquimod } \\
\hline \multicolumn{2}{|l|}{ Sinecatechins } \\
\hline \multicolumn{2}{|l|}{ Interferons } \\
\hline \multicolumn{2}{|l|}{ Bacillus Calmette-Guerin } \\
\hline HPV vaccine & \\
\hline
\end{tabular}


Podophyllum resin: Podophyllum resin is a plant-based resin that arrests cell division at metaphase and induces apoptosis. A $25 \%$ solution applied directly on the warts with a cotton swab by the clinician. No more than 0.5 $\mathrm{mL}$ should be used in each treatment period and wide areas $\left(10 \mathrm{~cm}^{2}\right.$ or more) should not be treated in a single application because of potential pain and destructive area. The area should air-dry before the patient dresses. Podophyllum resin is avoided in pregnancy. In contrast to podophyllotoxin, systemic absorption and toxicity have been documented. A dilute solution (10\%) should be applied when treating broad warts to minimize total systemic absorption, and application to open lesions/ wounds should be avoided. The treatment is repeated weekly for four to six weeks, or until the lesions have cleared. ${ }^{33,43}$

Trichloroacetic acid and bichloroacetic acid: Both TCA and BCA are corrosive acids that damage the wart by chemical coagulation of tissue proteins. TCA is used most commonly, and can be used on the vulva and vagina, and during pregnancy. An 80 to 90\% TCA solution is applied carefully to the wart with a cotton swab; the wart turns white as the solution dries. Application of an ointment or gel to the normal area surrounding the wart can prevent the destruction of unaffected tissue. TCA treatment is suitable for small area of vaginal warts (eg, $\leq 5$ small warts). ${ }^{41}$ If excess TCA is applied, it can be antagonized by washing with soap or sodium bicarbonate solution. The patient should not sit, stand or dress until the treatment area has dried. The treatment should be applied weekly for four to six weeks, or until the lesions disappeared. The only study evaluating the use of TCA in women reported a 70 percent clearance rate. ${ }^{44}$

Fluorouracil: Fluorouracil (FU) is a pyrimidine antimetabolite that hinder methylation of deoxyuridylic acid in DNA synthesis, causing to apoptosis. Topical FU is often less tolerable due to side effects (burning, pain, inflammation, edema, or painful ulcerations). It should not be used during pregnancy. A gel consisting of FU is injected intradermally directly under the wart. Injections are performed once per week for up to six weeks. Clearance rates of $65 \%$ after treatments have been reported. ${ }^{45}$ Pref- erably, a thin layer of 1 or $5 \%$ cream has been applied on vulvar or vaginal warts to make a chemical desquamation. ${ }^{46-48}$ Several dosing protocols have been suggested, ranging from twice daily application to once weekly for several weeks. Zinc oxide cream or petroleum jelly can be applied to unaffected areas as a barrier to help protect against ulceration. ${ }^{47,48}$

\section{Immune-mediated therapies}

Both imiquimod and interferon initiate a local immune response at the site of the wart that ultimately may clear the lesions. Imiquimod and topical interferon may be self-administered; injectable interferon is given in the office. Experience with these agents is more limited than for other medical therapies. ${ }^{49-53}$

Imiquimod: Imiquimod is a toll-like receptor 7 agonist, which acts as a positive immune response modifier, and stimulates local cytokine induction. Two formulations are available, Aldara (5\% imiquimod) and Zyclara (3.75\% imiquimod). There are no comparative data available between the two dosing regimens. The manufacturers recommend against vaginal administration. The patient applies imiquimod cream directly to the clean dry warty tissue at bedtime, rubbing it in until the cream is no longer visible; this area is washed with mild soap and water 6 to 10 hours later. Sexual contact should be avoided while the cream is on the skin. The cream can weaken condoms and diaphragms. Aldara is applied three days per week for up to 16 weeks. ${ }^{49}$ Zyclara is applied daily for up to 8 weeks. Forty to $50 \%$ of women will have complete clearance of the warts and most of the remainder will have partial clearance, but up to $30 \%$ will experience a recurrence within 12 weeks. ${ }^{50}$ The use of imiquimod in pregnancy should be avoided ${ }^{33}$ and its higher cost is a disadvantage.

Sinecatechins: Sinecatechins (eg, Veregen) is a botanical drug product for self-administered topical treatment of external AGWs. The active ingredient is kunecatechins, which are a mixture of catechins and other components of green tea. They have both antioxidant and immune enhancing activity. ${ }^{51}$ A $0.5 \mathrm{~cm}$ strand of ointment is placed on each wart and a finger is used to cover the wart with a thin layer of the ointment 3 times each day 
for up to 16 weeks. It should not be used in the vagina or anus and should be washed off of the skin before sexual contact or before inserting a tampon into the vagina. Sinecatechins should be avoided in immunocompromised women and women with active genital herpes lesions. There is minimal information on the risk of use during pregnancy. ${ }^{51}$

Interferons: Interferons have antiviral, antiproliferative, and immune-stimulating effects, theoretically making them an ideal agent for treatment of anogenital warts. Interferon-alpha and -beta have been administered as a systemic therapy (intramuscular injection), topically, and as a subcutaneous intralesional injection. Placebo controlled randomized trials have generally found intralesional therapy to be most effective, ${ }^{52}$ while evidence for the efficacy of systemic and topical therapy has been inconsistent. ${ }^{53-56}$ Intralesional injection of 0.5 to 1.5 million international units per lesion is administered two to three times per week for up to three weeks. The course of therapy can be repeated 12 to 16 weeks from the initial treatment. Local anesthesia is recommended. ${ }^{57}$ Interferon may be used as adjunctive therapy to surgical and cyto-destructive treatments, especially in patients with refractory lesions. Interferons are contraindicated in pregnancy. ${ }^{53-56}$

Bacillus Calmette-Guerin: Topical administration of bacillus Calmette-Guerin (BCG) has been used primarily for treatment of perianal warts in men and requires further study. ${ }^{58-60}$

$H P V$ vaccine: $H P V$ vaccines are effective in the primary prevention of HPV infection. ${ }^{33}$

\section{Surgical therapy}

Surgical management options consist of ablative and excisional procedures. Especially in patients with extensive or multifocal disease, surgical treatment modalities are used. Regardless of the method chosen, the surgeon should maintain control of the depth of tissue destruction due to the risk of fistula formation. An advantage of surgical management is that fewer visits for treatment are needed compared with medical therapy. A disadvantage of all surgical therapies is that they generally re- quire anesthesia and often need to be performed in an operating room. Surgical therapy may result in hypopigmentation, hyperpigmentation and scarring, especially when the subdermal layer is destroyed.

Biopsy is recommended to rule out underlying intraepithelial neoplasia or cancer prior to surgical treatment of lesions that are refractory to medical therapy or appear atypical. If performed, biopsy must be done prior to using any ablative technique. All of the surgical options can be used in pregnant women and on both the vulva and vagina. ${ }^{33,61-64}$

Cryoablation: Cryoablation with either liquid nitrogen or nitrous oxide destroys wart tissue via cell lysis. Although it is an office procedure, cryoablation causes pain during application and variable localized inflammation afterward. Providing local anesthesia for the procedure is especially important when the area undergoing cryotherapy is extensive. ${ }^{61}$

Liquid nitrogen is most commonly used, and is applied directly to the vulvar or vaginal lesion with a cotton swab or a fine spray. The treatment is applied for 30 to 60 seconds, until an ice ball forms and encompasses the lesion and 1 to $2 \mathrm{~mm}$ surrounding area. ${ }^{61}$ Repeated weekly application is required until the lesions have resolved.

Nitrous oxide is dispensed via a cryoprobe and generally gives a greater depth of freezing; therefore, it is not recommended for use in the vagina because of the risk of vaginal perforation and fistula formation. ${ }^{33}$

Laser ablation: Lasers produce light energy, which is absorbed by water within warty tissues, leading to thermal damage and resultant ablation. Carbon dioxide laser is the most commonly utilized type of laser for treatment of vulvar warts, but requires specific training and specialized equipment. ${ }^{62}$ Laser ablation is the preferred therapy than the surgical knife for extensive or multifocal vulvar lesions to maintain normal vulvar anatomy. Laser is also useful for treating vaginal warts when surgical excision is technically challenging or not feasible. The risks of laser surgery include scar formation (up to 28 percent), pain, hypopigmentation and vulvodynia. ${ }^{63,64}$ 
The surgeon and operating room personnel should wear protective masks when performing laser ablation, as HPV DNA can be dispersed in the laser plume. ${ }^{65} \mathrm{~Pa}-$ tients are instructed to take sitz baths two to three times a day during the initial one to two weeks following the procedure for pain management. Antibacterial creams or ointments are suggested to prevent superficial infection, as well as to separate the vulvar folds and prevent agglutination of tissues. ${ }^{62-65}$

Electrocautery: Electrocautery can also be used for ablation of vulvar or vaginal lesions. An advantage of this approach over cryoablation is that a single treatment session is usually adequate for eliminating the warts. A disadvantage is that electrocautery requires administration of anesthesia and use of an operating room. If available, laser ablation is generally preferable to electrocautery because it is associated with less bleeding and discomfort following the procedure. ${ }^{33}$

Ultrasonic aspiration: The Cavitron ultrasonic aspirator (CUSA) technique utilizes ultrasound to fragment and aspirate warty tissue. ${ }^{66}$ This allows removal of epithelium without damage to underlying tissue.

Excision: If tissue is needed for histological diagnosis, an excisional biopsy can be performed before an ablative procedure, or an excisional procedure can be performed. Typically, exophytic lesions are tangentially excised or shaved to the level of normal skin using scissors or a surgical knife, and then the base of the lesion is cauterized. ${ }^{67}$ Curettage or electrosurgery can also be used for excision of lesions. Adverse sequelae of excisional therapy include pain, dyspareunia, scar formation, and infection. ${ }^{61}$

\section{Treatment of AGWs in pregnancy}

No studies have compared occurrence and course of clinical warts in pregnant and non-pregnant patients. Few studies have evaluated HPV in pregnancy and most showed an increase in prevalence. ${ }^{68,69}$

Indications for treatment of AGWs in pregnant women are similar to those for non-pregnant women. In addition, lesions that potentially obstruct the birth canal should be treated to avoid complications during vaginal birth. Treatment may not reduce the risk of vertical transmission. Treatment options are limited in pregnancy because podophyllin, podophyllotoxin, interferon, and FU are all contraindicated because of potential fetal harm. However, given the scarcity of data on use of imiquimod or sinecatechins in pregnancy, these drugs are generally not recommended..$^{33}$ TCA has no systemic absorption and no known fetal effects; therefore, it is the preferred medical treatment for pregnant women. Clearance rates are highest and recurrence rates lowest when TCA is used in the second half of the pregnancy. ${ }^{70}$ Cryoablation is also considered a safe and effective treatment for use in pregnancy. ${ }^{71,72} \mathrm{~A}$ number of case series have described use of laser ablation in pregnancy for bulky, potentially obstructive lesions, with success rates of 90 to $100 \% .^{73,74}$ The risk of wart recurrence appears lowest when the treatment is delayed until the third trimester. ${ }^{75}$

\section{Recommendations}

- Imiquimod or podophyllotoxin (podofilox) is recommended for initial therapy of a small area of external genital warts (eg, $\leq 5$ small warts) ${ }_{,}^{41}$ as long as the patient can comply with home therapy.

- Podophyllotoxin (podofilox) has negligible systemic absorption/toxicity, and can be self-administered, and is more effective than podophyllum resin (podophyllin). Comparative studies have shown that podophyllotoxin is more effective than podophyllum resin for clearance of all warts. ${ }^{76,77}$

- Sinecatechins are a reasonable alternative, but the most costly approach.

- Trichloroacetic acid (TCA) and cryotherapy are recommended for initial office-based treatment of women who cannot comply with self-administered therapy or as a second-line approach for those who fail home therapy. ${ }^{34,78}$ TCA can be used in combination with imiquimod for patients who fail monotherapy or cryotherapy. ${ }^{78}$

- TCA, BCA, and interferons are the only medications that can be used to treat vaginal warts, but many patients cannot tolerate intralesional interferons. Laser ab- 
lation is our preferred surgical approach as it is possible to reach into the vagina and the depth of treatment can be controlled.

- For patients with extensive ( $\left.>20 \mathrm{~cm}^{2}\right)$ and/or bulky disease, surgery as initial therapy is recomended because medical therapy alone often requires a prolonged course of treatment and is often inadequate and poorly tolerated. Laser ablation is less destructive and less technically challenging than excision, and better tolerated than electrocautery.

- For patients with multifocal or refractory disease, a combination of techniques is often effective. For these patients a surgical approach or a combination of intralesional interferon and TCA can be used. For patients with recurrent disease, the same treatment that resulted in initial clearance of warts may be used again and is likely to be successful.

- Postmenopausal women who present with warty-appearing lesions should be biopsied before initiation of therapy, as these women have a greater chance of having an underlying vulvar intraepithelial neoplasia or vulvar cancer than younger women.

\section{Conclusion}

HPV infection is a global public health problem leading to an economic burden accounting for the costs of the treatment of AGWs and HPV-associated neoplasies. The patient should be evaluated by a multidisciplinary approach including dermatologists, gynecologists, urologists, general surgeons and ear, nose, and throat specialists. The main goal dealing with this problem should primarily be to raise public awareness about HPV infection. Patients should be educated about transmission routes, prevention of transmission and the importance of vaccination.

\section{References}

1. Yanofsky VR, Patel RV, Goldenberg G. Genital warts: a comprehensive review. J Clin Aesthet Dermatol. 2012;5:25-36.

2. Bhatia N, Lynde C, Vender R, Bourcier M. Understanding genital warts: epidemiology, pathogenesis, and burden of disease of human papillomavirus. J
Cutan Med Surg 2013;17 Suppl 2:47-54.

3. Kirnbauer R, Lenz P. Human papillomaviruses. In: Dermatology (Bolognia JL, Jorizzo JL, Schaffer JV, eds.), 3rd ed. Elsevier Saunders, 2012;1383-99.

4. Leszczyszyn J, Lebski I, Lysenko L, Hirnle L, Gerber H. Anal warts (condylomata acuminata) - current issues and treatment modalities. Adv Clin Exp Med 2014;23:307-11.

5. Steben M, Duarte-Franco E. Human papillomavirus infection: epidemiology and pathophysiology. Gynecol Oncol 2007;107:2-5.

6. Tchernev G. Sexually transmitted papillomavirus infections: epidemiology pathogenesis, clinic, morphology, important differential diagnostic aspects, current diagnostic and treatment options. An Bras Dermatol 2009;84:377-89.

7. Patel H, Wagner M, Singhal P, Kothari S. Systematic review of the incidence and prevalence of genital warts. BMC Infect Dis 2013;13:39.

8. Leung AK, Barankin B, Leong KF, Hon KL. Penile warts: an update on their evaluation and management. Drugs Context 2018;7:212563.

9. Berman TA, Schiller JT. Human papillomavirus in cervical cancer and oropharyngeal cancer: One cause, two diseases. Cancer 2017;123:2219-29.

10. Costa-Silva M, Fernandes I, Rodrigues AG, Lisboa C. Anogenital warts in pediatric population. An Bras Dermatol 2017;92:675-81.

11. Harden ME, Munger K. Human papillomavirus molecular biology. Mutat Res Rev Mutat Res 2017;772:3-12.

12. Graham SV. The human papillomavirus replication cycle, and its links to cancer progression: a comprehensive review. Clin Sci 2017;131:2201-21.

13. Woappi Y, Hosseinipour M, Creek KE, Pirisi L. Stem cell properties of normal human keratinocytes determine transformation responses to human papillomavirus 16 DNA. J Virol 2018;92:e00331-18.

14. Maglennon GA, McIntosh P, Doorbar J. Persistence of viral DNA in the epithelial basal layer suggests a model for papillomavirus latency following immune regression. Virology 2011;414:153-63.

15. Gravitt PE, Winer RL. Natural History of HPV Infection across the Lifespan: Role of Viral Latency. Viruses 2017;9:267.

16. Sporkert M, Rubben A. Buschke-Lowenstein tumors. Hautarzt 2017;68:199-203.

17. Hornor G. Ano-genital warts in children: Sexual abuse or not?. J Pediatr Health Care 2004;18:165-70.

18. Ambuhl LM, Baandrup U, Dybkær K, et al. Human papillomavirus infection as a possible cause of spontaneous abortion and spontaneous preterm delivery. Infect Dis Obstet Gynecol 2016;2016:3086036.

19. Mammas IN, Dalianis T, Doukas SG, et al. Paediatric 
virology and human papillomaviruses: An update. Exp Ther Med 2019;17:4337-43.

20. Gormley RH, Kovarik CL. Human papillomavirus-related genital disease in the immunocompromised host: Part I.J Am Acad Dermatol 2012;66:867.

21. Maw RD, Reitano M, Roy M. An international survey of patients with genital warts: perceptions regarding treatment and impact on lifestyle. Int J STD AIDS 1998;9:571-8.

22. Mortensen GL, Larsen HK. The quality of life of patients with genital warts: a qualitative study. BMC Public Health 2010;10:113.

23. Sturgiss EA, Jin F, Martin SJ, Grulich A, Bowden FJ. Prevalence of other sexually transmissible infections in patients with newly diagnosed anogenital warts in a sexual health clinic. Sex Health 2010;7:55-9.

24. de Sanjose S, Quint WG, Alemany L, et al; Retrospective International Survey and HPV Time Trends Study Group. Human papillomavirus genotype attribution in invasive cervical cancer: a retrospective cross-sectional worldwide study. Lancet Oncol 2010;11:1048-56.

25. Chan PK, Picconi MA, Cheung TH, Giovannelli L, Park JS. Laboratory and clinical aspects of human papillomavirus testing. Crit Rev Clin Lab Sci 2012;49:117-36.

26. Gross G. Genitoanal human papillomavirus infection and associated neoplasias. Curr Probl Dermatol 2014:45:98-122.

27. Serrano B, Brotons M, Bosch FX, Bruni L. Epidemiology and burden of HPV-related disease. Best Pract Res Clin Obstet Gynaecol 2018;47:14-26.

28. Shimizu A, Kuriyama Y, Hasegawa M, Tamura A, Ishikawa O. Nail Squamous Cell Carcinoma: A hidden high-risk HPV reservoir for sexually transmitted infections. J Am Acad Dermatol 2019. pii: S0190-9622(19)30514-6.

29. Cho CY, Lo YC, Hung MC, et al. Risk of cancer in patients with genital warts: A nationwide, population-based cohort study in Taiwan. PLoS One 2017;12:e0183183.

30. Blomberg M, Friis S, Munk C, Bautz A, Kjaer SK. Genital warts and risk of cancer: a Danish study of nearly 50000 patients with genital warts. J Infect Dis 2012;205:1544-53.

31. Chae JY, Bae JH, Yoon CY, et al.Female urethral condyloma causing bladder outlet obstruction. Int Neurourol J 2014;18:42-4.

32. Steben M, LaBelle D. Genital warts: Canadians' perception, health-related behaviors, and treatment preferences. J Low Genit Tract Dis 2012;16:409-15.

33. Workowski KA, Bolan GA, Centers for Disease Control and Prevention. Sexually transmitted diseases treatment guidelines, 2015. MMWR Recomm Rep
2015;64:1-137.

34. Lacey CJ, Woodhall SC, Wikstrom A, Ross J. 2012 European guideline for the management of anogenital warts. J Eur Acad Dermatol Venereol 2013;27:263-70.

35. Schoenfeld A, Ziv E, Levavi $\mathrm{H}$, et al. Laser versus loop electrosurgical excision in vulvar condyloma for eradication of subclinical reservoir demonstrated by assay for 2'5' oligosynthetase human papillomavirus. Gynecol Obstet Invest 1995;40:46-51.

36. Ferenczy A, Mitao M, Nagai N, et al. Latent papillomavirus and recurring genital warts. N Engl J Med 1985;313:784-8.

37. Stern PL, van der Burg SH, Hampson IN, et al. Therapy of human papillomavirus-related disease. Vaccine 2012;5:71-82.

38. Sycuro LK, Xi LF, Hughes JP, et al. Persistence of genital human papillomavirus infection in a longterm follow-up study of female university students. J Infect Dis 2008;198:971-8.

39. American College of Obstetricians and Gynecologists. ACOG Practice Bulletin. Clinical management guidelines for obstetrician-gynecologists. Number 61, April 2005. Human papillomavirus. Obstet Gynecol 2005;105:905-18.

40. Vance JC, Davis D. Interferon alpha-2b injections used as an adjuvant therapy to carbon dioxide laser vaporization of recalcitrant ano-genital condylomata acuminata. J Invest Dermatol 1990;95:146-8.

41. Beutner KR, Reitano MV, Richwald GA, Wiley DJ. External genital warts: report of the American Medical Association Consensus Conference. AMA Expert Panel on External Genital Warts. Clin Infect Dis 1998;27:796-806.

42. Gunter J. Genital and perianal warts: new treatment opportunities for human papillomavirus infection. Am J Obstet Gynecol 2003;189:3-11.

43. Bonnez W, Elswick RK Jr, Bailey-Farchione A, et al. Efficacy and safety of $0.5 \%$ podofilox solution in the treatment and suppression of anogenital warts. Am J Med 1994;96:420-5.

44. Abdullah AN, Walzman M, Wade A. Treatment of external genital warts comparing cryotherapy (liquid nitrogen) and trichloroacetic acid. Sex Transm Dis 1993;20:344-5.

45. Swinehart JM, Skinner RB, McCarty JM, et al. Development of intralesional therapy with fluorouracil/ adrenaline injectable gel for management of condylomata acuminata: two phase II clinical studies. Genitourin Med 1997;73:481-7.

46. Heaton CL. Clinical manifestations and modern management of condylomata acuminata: a dermatologic perspective. Am J Obstet Gynecol 1995; 172:1344-50. 
47. Pride GL. Treatment of large lower genital tract condylomata acuminata with topical 5-fluorouracil. J Reprod Med 1990;35:384-7.

48. Krebs HB. Treatment of genital condylomata with topical 5-fluorouracil. Dermatol Clin 1991;9:333-41.

49. Gotovtseva EP, Kapadia AS, Smolensky MH, Lairson DR. Optimal frequency of imiquimod (aldara) 5\% cream for the treatment of external genital warts in immunocompetent adults: a meta-analysis. Sex Transm Dis 2008;35:346-51.

50. Garland SM, Waddell R, Mindel A, et al. An open-label phase II pilot study investigating the optimal duration of imiquimod 5\% cream for the treatment of external genital warts in women. Int J STD AIDS 2006; 17:448-52.

51. Meltzer SM, Monk BJ, Tewari KS. Green tea catechins for treatment of external genital warts. Am J Obstet Gynecol 2009;200:233.

52. Dinsmore W, Jordan J, O'Mahony C, et al. Recombinant human interferon-beta in the treatment of condylomata acuminata. Int J STD AIDS 1997;8:622-8.

53. Recurrent condylomata acuminata treated with recombinant interferon alfa-2a. A multicenter double-blind placebo-controlled clinical trial. Condylomata international collaborative study group. JAMA 1991;265:2684-7.

54. Reichman RC, Oakes D, Bonnez W, et al. Treatment of condyloma acuminatum with three different interferon-alpha preparations administered parenterally: a double-blind, placebo-controlled trial. J Infect Dis 1990;162:1270-6.

55. Olmos L, Vilata J, Rodriguez Pichardo A, et al. Double-blind, randomized clinical trial on the effect of interferon-beta in the treatment of condylomata acuminata. Int J STD AIDS 1994;5:182-5.

56. Syed TA, Khayyami M, Kriz D, et al. Management of genital warts in women with human leukocyte interferon-alpha vs. podophyllotoxin in cream: a placebo-controlled, double-blind, comparative study. J Mol Med (Berl) 1995;73:255-8.

57. Wiley DJ, Douglas J, Beutner K, et al. External genital warts: diagnosis, treatment, and prevention. Clin Infect Dis 2002;35:210-24.

58. Cook K, Brownell I. Treatments for genital warts. J Drugs Dermatol 2008;7:801-7.

59. Bohle A, Buttner H, Jocham D. Primary treatment of condylomata acuminata with viable bacillus Calmette-Guerin. J Urol 2001;165:834-6.

60. Metawea B, El-Nashar AR, Kamel I, et al. Application of viable bacille Calmette-Guerin topically as a potential therapeutic modality in condylomata acuminata: a placebo-controlled study. Urology 2005;65:247-50.

61. Ting PT, Dytoc MT. Therapy of external anogenital warts and molluscum contagiosum: a literature review. Dermatol Ther 2004;17:68-101.

62. Bellina JH. The use of the carbon dioxide laser in the management of condyloma acuminatum with eightyear follow-up. Am J Obstet Gynecol 1983;147:375-8.

63. Baggish MS. Improved laser techniques for the elimination of genital and extragenital warts. Am J Obstet Gynecol 1985;153:545-50.

64. Ferenczy A. Laser therapy of genital condylomata acuminata. Obstet Gynecol 1984;63:703-7.

65. Ferenczy A, Bergeron C, Richart RM. Carbon dioxide laser energy disperses human papillomavirus deoxyribonucleic acid onto treatment fields. Am J Obstet Gynecol 1990;163:1271-4.

66. Rader JS, Leake JF, Dillon MB, Rosenshein NB. Ultrasonic surgical aspiration in the treatment of vulvar disease. Obstet Gynecol 1991;77:573-6.

67. Gollock JM, Slatford K, Hunter JM. Scissor excision of anogenital warts. Br J Vener Dis 1982;58:400-1.

68. Rando RF, Lindheim S, Hasty L, et al. Increased frequency of detection of human papillomavirus deoxyribonucleic acid in exfoliated cervical cells during pregnancy. Am J Obstet Gynecol 1989;161:50-5.

69. Kemp EA, Hakenewerth AM, Laurent SL, et al. Human papillomavirus prevalence in pregnancy. Obstet Gynecol 1992;79:649-56.

70. Ferenczy A. HPV-associated lesions in pregnancy and their clinical implications. Clin Obstet Gynecol 1989;32:191-9.

71. Bergman A, Matsunaga J, Bhatia NN. Cervical cryotherapy for condylomata acuminata during pregnancy. Obstet Gynecol 1987;69:47-50.

72. Matsunaga J, Bergman A, Bhatia NN. Genital condylomata acuminata in pregnancy: effectiveness, safety and pregnancy outcome following cryotherapy. Br J Obstet Gynaecol 1987;94:168-72.

73. Schwartz DB, Greenberg MD, Daoud Y, Reid R. Genital condylomas in pregnancy: use of trichloroacetic acid and laser therapy. Am J Obstet Gynecol 1988;158:1407-16.

74. Adelson MD, Semo R, Baggish MS, Osborne NG. Laser vaporization of genital condylomata in pregnancy. J Gynecol Surg 1990;6:257-62.

75. Arena S, Marconi M, Frega A, Villani C. Pregnancy and condyloma. Evaluation about therapeutic effectiveness of laser CO2 on 115 pregnant women. Minerva Ginecol 2001;53:389-96.

76. Lacey CJ, Goodall RL, Tennvall GR, et al. Randomised controlled trial and economic evaluation of podophyllotoxin solution, podophyllotoxin cream, and podophyllin in the treatment of genital warts. Sex Transm Infect 2003;79:270-5.

77. Hellberg D, Svarrer T, Nilsson S, Valentin J. Self-treatment of female external genital warts with $0.5 \%$ 
podophyllotoxin cream (Condyline) vs weekly applications of $20 \%$ podophyllin solution. Int J STD AIDS 1995;6:257-61.

78. Fine P, Ball C, Pelta M, et al. Treatment of external genital warts at Planned Parenthood Federation of America centers. J Reprod Med 2007;52:1090-6. 